\title{
Landscape functioning assessment based on radiation temperature distribution
}

\author{
PETRA HESSLEROVÁ \\ ENKI, o.p.s., Třeboň, Katedra aplikované geoinformatiky a územního plánování, \\ FŽP ČZU Praha
}

\begin{abstract}
The aim of the paper is to introduce approach of landscape functioning assessment based on the relationship of three land cover types (forest, bare ground, non-forest vegetation) and radiation temperature that is regarded as an indicator and way how the solar energy is dissipated within landscape. Land cover assessment of trans-boundary model area (Northern Bohemia and Saxony) was based on multispectral classification of Landsat TM data. Radiation temperature, qualified in relative scale was derived from the same sensor from thermal band TM6. The interpretation of processed satellite images results from theoretical background of Energy-transport-reaction model. The results demonstrate that temperature is distributed across landscape depending on the type and structure of land cover. Unless damaged, forest ecosystems are able to maintain lower temperatures and produce condensation places. By contrast, non-forest vegetation tends to fall into the category of low dissipation ability and higher temperature. More positive trends are visible in some types of permanent grass vegetation, especially wet meadows. Bare surfaces, by contrast, contribute to high temperatures, release heat and contribute to landscape warming.
\end{abstract}

Key words: Land cover - solar energy dissipation - Landsat TM - remote sensing - Northern Bohemia

\section{Introduction}

Landscape is a complex system with different functions. Most of its assessments are based on detailed structure analyses. However, there is a wide scale of approaches. Functional analyses are mainly connected with energy and matter flows, its balance and dynamics, either try to explain interaction between various components of ecosystem (Saunders et al. 1998). In addition there are other concepts with background in thermodynamics (Schneider and Kay 1994a, 1994b; Svirezhev 2000), food chain analyses (Patten, Masahiko and Burns 1990), biomass accumulation (Jørgensen and Mejer 1979), theories of information (Ulanowitz 1986), networks (Leibowitz et al. 2000), biological self-organization (Kutch et al. 2001) and many others.

Energy-transport reaction model by W. Ripl (1995) is one of them and deals with the dissipation of the daily energy pulse seasonally modulated by water and matter loss within the landscape. Maximal dissipation of this energy is considered to be 
a basic ecologic function of the landscape. Incident solar radiation is partly reflected, transmitted or absorbed. Absorbed solar radiation is transformed; the way how it is done is in a close relationship with land cover and its quality. In dependence on these parameters the absorbed radiation is either: conducted into soil (5-10\%), converted by evapotranspiration into latent heat $(20-80 \%)$ or into sensible heat, and stored in biomass by photosynthesis (0.45-3\%). Functional landscape dissipates solar energy so as to balance temperature amplitudes, retain water, solved and dissolved matter. The key factor is water, its short and close cycle. It means circulation of water in which water evaporated on land falls in the form of precipitation over this same terrestrial environment. Water should be considered not only in "natural form"; vegetation water content is important as well. Permanent and functional vegetation with high moisture content presents evapotranspiration and condensation "units" within landscape, able to cope with local and temporal temperature differences and retain water. Forests, wet meadows and wetlands are considered as such type of vegetation. Ideally $80 \%$ of incident solar radiation is converted via evapotranspiration into latent heat, which not contribute to temperature rise. Human activities (agriculture, urbanization, exploitation) mainly contribute to destruction of natural and functional vegetation cover from landscape, as well as to its drainage. It results in loss of important condensation areas and openness of water cycle. Water deficit leads to decrease of evapotranspiration rates (to $10-20 \%$ ), I terms of dissipation it causes increase of sensible heat, consequently accompanied with temperature rise, higher amplitudes, rainfall imbalance, accelerated matter losses and decomposition. There are both direct and indirect effects of temperature on water cycle (rainfall distribution and intensity, its source, water quality, aquifer level), local and global climate (circulation systems, wind, convection flows, and air humidity), and matter loss (Pokorný 2001; Procházka et al. 2001; Hais et al. 2006; Pecharová et al. 2006).

There are not so many papers dealing with surface temperature as a main indicator of ecosystem functioning. Some of them analyze its relationship with land cover type (Melesse 2004; Saunders et al. 1998), amount of biomass (Smith and Choudhury 1991), complexity of ecosystem (Holbo and Luvall 1989). The more advanced succession, the lower temperature and amount of radiated energy. The mature ecosystems dissipate energy in higher level; on the contrary stress factors and immature stands lower this ability and speed the matter losses.

To determine energetic efficiency of landscape and the way, how it is dissipated, multispectral and thermal remote sensing data from Landsat TM and ETM+ could be use. Channel TM6 (10.4-12.5 $\mu \mathrm{m})$ scan thermal radiance of Earth's surface, with a spatial resolution $120 \mathrm{~m}, 60 \mathrm{~m}$ eventually. The main significance is that there is no need of data interpolation and in addition the real (kinetic) temperature could be derived as well. However, change-over time analyses require usage of relative surface temperature; real temperature data are not advisable, because of distinctive illumination of scenes in different dates of their acquisition, different phenological phases and meteorological conditions as well. 
As a model area cross-boarder region of Northern Bohemia and Saxony was chosen, approximately delineated by line Chemnitz - Neustadt in Sachsen - Děčín Slaný - Podbořany - Doupovské Mountains - Loučná pod Klínovcem - Chemnitz.

Different landscape types, physical-geographical conditions and socioeconomics aspects, determine the heterogeneity of this area. All characteristics form the dynamics and landscape development, its structure and functioning. Such diversity enables to compare and contrast agriculture areas with different way of its management (Dolnooharská Table versus Saxony). Both regions are separated by the Krušné Mountains; the area was in eighties affected by extremely high rates of sulfur oxides immisions that resulted in total decay of forests. Disturbed opencast coal-mining landscape of Most Basin belongs to the most troubleshooting regions in the Czech Republic, however gradual reclamation try to restore functional landscape again. The Doupovské Mountains, from 1953 military area without public access and harmonious landscape of České středohoří are other specifics of model area.

The model area $(102.3 \times 85.23 \mathrm{~km})$ is situated in $192-025$ scene, date of acquisition 1. 7. 1995 a 10. 8. 2004.

\section{Methods}

Land cover classification scheme was compiled with a respect to different dates of scene acquisition, spatial resolution of Landsat data (30 meters) and size of model area $\left(8722 \mathrm{~km}^{2}\right)$. For the purpose of landscape functioning assessment determination of four basic land cover types - water bodies, forests, non-forest vegetation and bare ground was considered as sufficient. More detailed classification into other sub-categories is limited by the date of scene acquisition the July term is not advisable. Differentiation of non-forest vegetation into arable land (crops) and permanent grassland was based on parallel visualization RGB synthesis of channels TM 4-5-3. The information about land cover got from multispectral Landsat TM data by methods of supervised classification (Maximum Likelihood, Fisher Linear Likelihood and ECHO). Because of nearly identical spectral response of deciduous forests and non-forest vegetation, it was difficult to separate both categories within the scene 1995. Consequently the overall accuracy of classification, gained from error matrix based on test field selection, was only $90.1 \%$, in a comparison with $98.1 \%$ of August 2004 scene that is more acceptable for land cover analyses.

Maps of relative surface temperature have been created from accrued histogram values of thermal channel TM6 by method of quantils. Five thermal categories (each contained $20 \%$ of pixels) were labeled as areas with lowest temperature - low middle - high - highest temperature. It is advisable to be aware of the fact that such defined temperature classes are related to specific area and will differ with a selection of the other. The temperature for individual land cover classes have been derived from the overall temperature map by the process of masking. The results are presented by 
column charts. Cross-classification analyses (module CROSSTAB in IDRISI 15.0) have been used to assess temperature change-over-time.

The interpretation of thermal images in terms of solar energy dissipation has a background in Energy-transport-reaction model (Ripl 1995). In accordance with this theory, areas where majority of solar radiation is, due to lack of water, low evapotranspiration rate and absence of functional land cover, converted into "sensible heat", are characterized by highest temperature categories. On the contrary, areas where solar radiation is released as "latent heat" are presented by lowest categories of temperature. The temperature distribution influences local climate, water cycle, matter flow etc. as mentioned in "Introduction" section.

\section{Results}

Resulting from the overall maps of temperature (Figure 1a, b), its distribution is highly uneven, characterized by regional and time differences (Figure 2). The areas that are classed as the lowest temperature should be considered as condensation units within the landscape, able to retain higher humidity, low temperature amplitudes and via evapotranspiration effectively dissipate solar energy into latent heat. On the contrary areas categorized to highest temperature classes are characterized by removal of permanent vegetation cover, openness of small water cycle, low humidity and consequently low rates of evapotranspiration. In terms of energy dissipations it takes effect as sensible heat rise at the expense of latent heat. The landscape temperature rises, its amplitudes as well, consequently the matter losses are accelerated.

Relative radiation temperature was analyzed in relation to land cover. Extended analyses (Hesslerová 2008) including correlation analyses with digital elevation model did not reveal strong dependence on altitude. Type of vegetation and its quality aspects were recognized as main factors affecting temperature distribution within landscape.
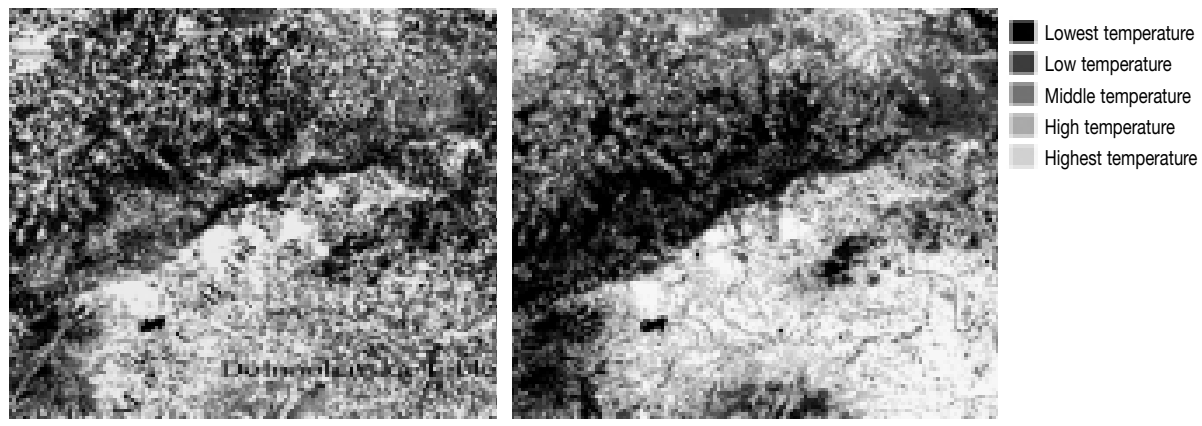

Figure 1: Relative radiation temperature of landscape derived from Landsat TM6 (a) 1. 7. 1995 and (b) 10. 8.2004 

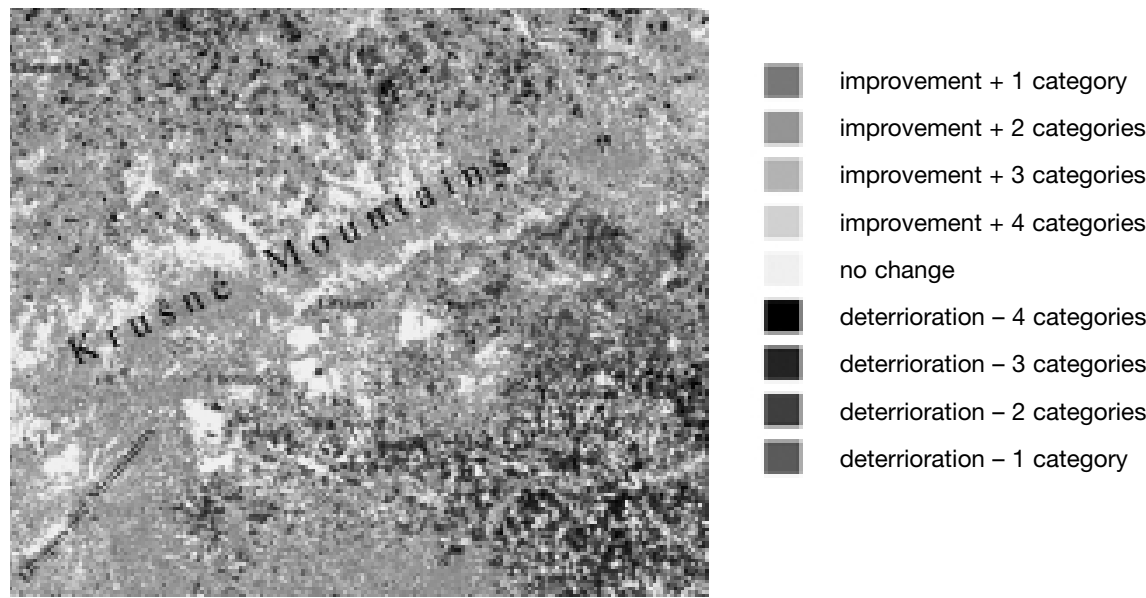

Figure 2: Changes of relative radiation temperature 1995-2004 are considered as indicators of landscape functioning

\section{Regional temperature assessment}

Large forests ecosystems in the Krušné and the Doupovské Mountains and the Děčínská Highlands are permanent and functional vegetation, with high dissipation ability, characterized by low temperature. However, there is a significant change in functioning. In 1995 there is still evident thermal stress not only at the top part of the Krušné Mountains, mainly in the areas of forest decay (Klínovec - Horní Jiřetín, surroundings of water reservoir Fláje), but in some areas in the Děčínská Highlands as well. High share of permanent grassland in these regions contribute to higher dissipation ability (low temperature in both terms). The positive assessment of the Doupovské Mountains makes allowance for restriction of management activities in fifties. East, public accessible, part of this region shows positive development (in 2004), caused by higher share of permanent grassland, scattered vegetation and abandonment of arable land. Large and homogeneous areas of high temperature have been fragmented into smaller units or substituted by lower temperature categories.

Nearly the same trend is typical of Džbán region. Local forests are characterized by high dissipation ability, except 1995, when thermal vegetation stress appeared. In 2004 there was a positive trend of development - landscape is more heterogeneous (variation of scattered vegetation, forests, meadows, agriculture areas). Such heterogeneity contributes to increased dissipation ability of the landscape. Presence of large localities with lower dissipation ability (high temperature) in 1995 is compensated by its fragmentation in 2004, as a result of increase total area of permanent grassland to crops.

Dolnooharská Table and Most Basin are regions in the long term exposed to thermal stress. The area is an objective example of negative effects of agriculture large blocks of arable land, absence of permanent vegetation can not compensate negative impacts of intensive exploitation of the area. Non-forest vegetation presented 
mainly by xerophillic crops is not able to dissipate solar radiation effectively. There is an ascendancy of sensible heat over latent component, accompanied with matter losses. Lack of condensation places leads to an openness of small water cycle and total loss of cooling ability. Forests, mainly fringing water-courses, in a comparison with agriculture areas do not extend on such areas to be able balance negative effects of overheated fields. It is evident in situation 2004. Positive trends are observed in the surroundings of the Ohře and between towns Postoloprty - Podbořany.

Surface mining areas in Most basin do not show many differences in a comparison with agriculture areas within Dolnooharská Table. Highest temperature is linked with dumps, opencast coal-mining, industrial areas and agglomerations. This region is generally considered as most devastated landscape in the Czech Republic, however, thanks to step-by-step reclamation processes gradual improvement and restoration of basic landscape functions could be observed. The restoration of scattered vegetation, via succession, has a positive effect on surface temperature. Especially in the area between Kopisty - Jirkov, in the surroundings of Horní Jiřetín, Chabařovice, Klášterec nad Ohří - Prunéřov, the effects of reclamation process have been observed within the mining areas (fragmentation and decrease in extent of warmest places).

As a result of land cover heterogeneity one can identify different landscape functional types within České středohoří. The middle part of the region is characterized by mosaics of forests, fields and permanent grassland. Such a landscape type dissipates energy effectively, predominantly into latent heat. Lower dissipation ability is bounded to the agriculture areas in the Elbe region and transition zones to Dolnooharská Table and Most Basin. This region is an example of positive effects of heterogeneous landscape. Although forests do not take up the major part of this region, their fragmentation and relatively even distribution enable to form favorable and balanced temperature distribution within landscape.

Because of distinctive socio-economic development in last fifty years, Saxony region is considered to be a harmonic and well-structured landscape. This region had not been intensively agriculturally used; therefore the area of blocks of arable land is, in a comparison with Czech landscape, completely different. Forests take up more integrated units at the Saxony part of the Krušné Mountains, towards the inland are more fragmented and relatively evenly distributed. In contrast to the Czech territory, Saxon part does not show symptoms of thermal stress. The only exception is Sächsische Schweiz in 1995. The increasing negative effect of urban heat islands can be observed mainly in Dresden and Chemnitz areas. This trend is not evident in the Czech part of model area, because majority of agglomerations is situated within the areas afflicted with thermal stress and merge with surroundings completely. Saxony is characterized by functional and heterogeneous landscape structure, with a mosaics of relatively evenly distributed stable areas, which are able to dissipate solar energy effectively, keep low landscape temperature and balance possible negative impact of hot spots.

There might be some objection that the whole region of Most Basin and Dolnooharská Table is under the influence of rain shadow. Logically one can anticipate high temperatures and water deficit. České středohoří (except Milešovka area), eventually the Džbán area and east part of Doupov regions are classified as warm climatic regions as well. However, it can be concluded from this work, the 
heterogeneous landscape structure, with functional vegetation can reduce landscape overheating. Account on that precipitation insufficiency, arrangements reducing these negative effects should be done. First step are changes in landscape structure - higher heterogeneity, shrinkage of fields and above all restoration of permanent and functional vegetation.

\section{Land cover impact on temperature distribution}

Temperature distribution of individual land cover types is displayed on Figures $3 \mathrm{a}, \mathrm{b}$ and 4 .

Bare grounds are characterized by the lowest dissipation ability. Complete removal of vegetation cover leads to total predominance of sensible heat over such areas. However, this negative effect could be reduced even with a small amount of dead biomass, as implies from situation 2004; higher humidity does not have required positive impact. Bare grounds are not represented only by urban and industrial areas, but by arable land as well. Intensive agriculture areas are presented as a highly devastated landscape, characterized by large heat islands. The similar response is typical for opencast coal-mining areas, industrial zones and agglomerations. In contrast to agriculture, those do not extend on such large areas; in some cases reclamation processes try to restore the functional landscape again. Resulting from the work, the fragmentation of large fields or inhibition managing activities could contribute to improve landscape functioning. Removing permanent and functional vegetation from the landscape causes its heating, drainage and degradation.

Non-forest vegetation is classified as a type with changeable or lower dissipation ability. Low evapotranspiration causes predominance sensible heat over latent heat and higher temperature of these areas. In most cases is represented by xerophillic crops, prone to thermal stress. Localities covered by non-forest vegetation in most cases cannot function as condensation unit within the landscape. This fact, significant mainly for crops, is displayed on the 1995 scene (Figure 3a), when the amount of green biomass is very high. Permanent grasslands appear in more positive way - they keep higher humidity and thereby lower temperature. In contrast to crops, which are
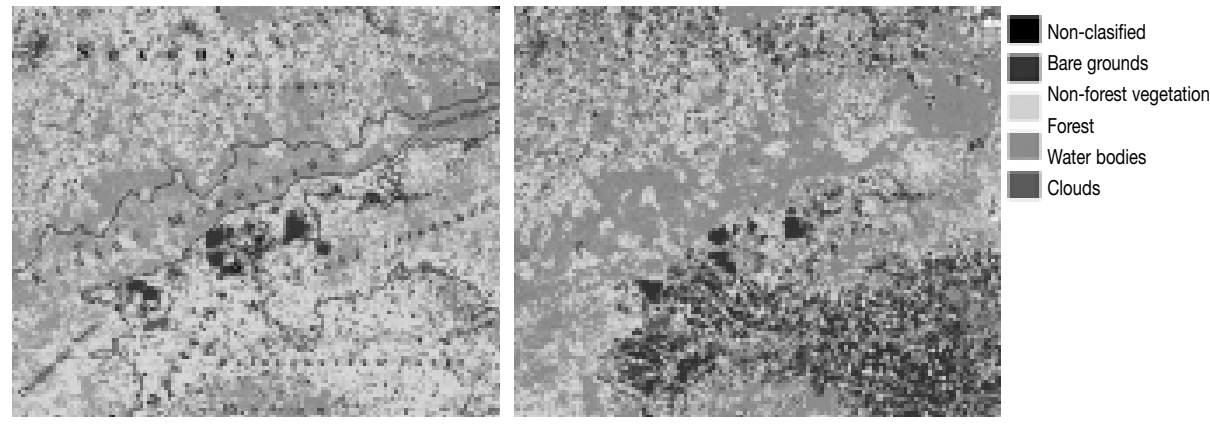

Figure 3: Land cover classification provided background information for different landscape type's assessment (a) 1.7. 1995 and (b) 10. 8. 2004 

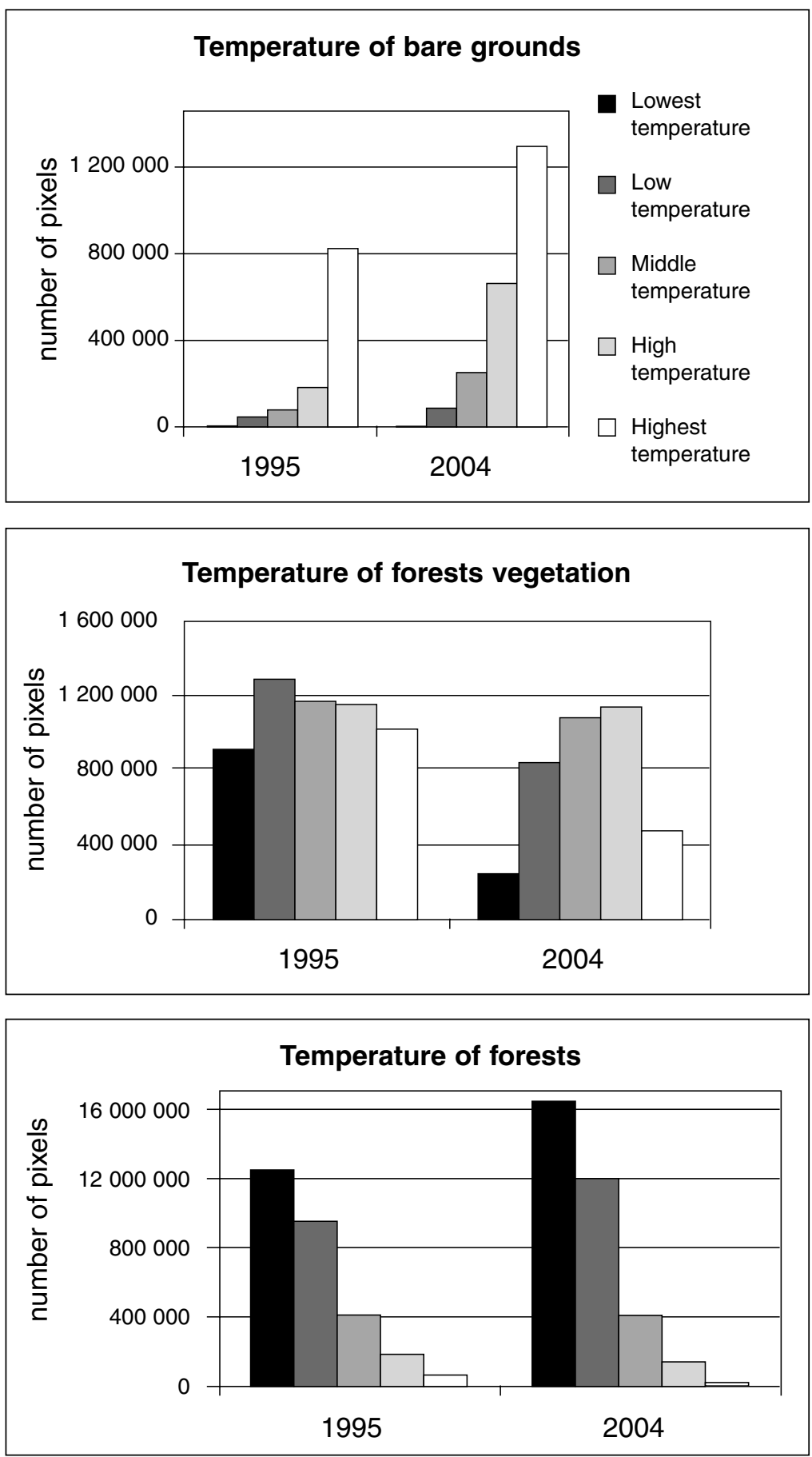

Figure 4: Graphs of temperature distribution of different land cover types 
harvested during July, represent more persistent vegetation type, as it is shown on Figure 3b. Such positive behavior is typical especially for wetlands and wet meadows, in smaller rate for meadows at forest margins.

Forest ecosystems should be considered as permanent and functional type of land cover, and characterized by high dissipation ability. This vegetation type is able to balance temperature amplitudes, keep higher humidity and effective dissipation of solar energy (latent heat prevails). If there is no influence of water deficit, like in term 1995 in the Krušné Mountains, the Děčínská Highlands and Džbán, they maintain low temperature. Resulting from situation 2004, scattered vegetation (bushes, holding cover) in Dolnooharská Table, shows lower dissipation ability. This fact could be caused by negative influence of surroundings that is extremely dry and hot agriculture land. Unequal rate of agriculture land and scattered vegetation causes, that is not able to cool such vast areas. To have a desired positive effect, their area and occurrence should be enlarged and landscape structure changed.

\section{Discussion}

It looks to be a common spoken topic; however, there are not so many papers to prove the potential of different land cover types and the heterogeneity of its structure with a respect to temperature and enable analysis of landscape functioning (Foley et al. 2003, 2005, Ripl and Hildmann 2000; Ripl 2004; Pokorný and Šíma 2006; Š́ma and Pokorný 2006). Remote sensing data provide the missing basis and proves for those statements. The seriousness of increasing landscape temperature is shown at the example of agriculture and industrial regions of the Most basin and the Dolnooharská table.

Global warming and climate changes are usually mentioned in a consequence of greenhouse gasses, eventually with albedo (CRFEC 2005, IPCC 2007, DeFries et al. 2002, Randerson et al. 2006, Bonan 2008). Processes of evapotranspiration and the significance of permanent green and functional vegetation are usually neglected. The agriculture intensification and urbanization are the main processes that affect energymaterial flows and energy dissipation within landscape (Foley et al. 2005). Drainage of vast areas, large scale vegetation disturbances (not only cutting forests, but even loss of many scattered trees, bushes, xerophilic crops preference) are ones of main causes of landscape overheating and its degradation, and results also in accelerated loss of nutrients (Hais et al. 2009). One does not have to consider only arid and semiarid regions, result from this paper, but lower reach of the Elbe and the Ohře catchments as well (Kliment et al. 2008). Incorporation of permanent vegetation to the landscape, even in regional scale will improve both temperature dissipation and water cycle, and consequently global climate. Temperature increase could be effectively controlled by those processes. Higher temperature amplitudes reflect in sinuous flows, lower evapotranspiration rates, damage of vegetation, speed up nutrient flow. The restoration of basic ecological functions as solar energy dissipation via water cycling is active and effective steps that could serve as a defence against global climate change and warming. 


\section{Conclusions}

Water and vegetation in the landscape are the determining factors for the way that solar energy is dissipated. Water deficiency leads to higher temperatures as sensible heat is produced and evapotranspiration (of latent heat) is suppressed. The way temperatures are distributed in landscape is an indicator of the ecosystem function and can be used as an indicator of the ability of the landscape to dissipate solar energy and, consequently, to balance out temperature differences. Real or relative radiation temperature can be observed through thermal images.

Forests ecosystems are characterized by high dissipation potential, which means incident solar radiation is dissipated mainly to latent heat (does not contribute to the temperature increase). They are able to balance temperature fluctuations and keep higher humidity. Provided there is no water deficit, they increase cooling capacity of the landscape. Non-forest vegetation is mainly defined by low dissipation potential. Crops, often grown at drained areas, prone to water stress, are not able to dissipate the solar radiation effectively. The intensity of evaporation process in such areas, is very low, the dominant component is sensible heat that consequently increase the landscape temperature. Only permanent grass stands as wet meadows and wetlands have positive effects. Bare grounds are usually classed as the hottest spots within the landscape. As satellite data shown, even small amount of non-green and dead biomass could slightly decrease the temperature.

Remote sensing data (Landsat - above all thermal TM6 channel) and basic methods of processing are the background of objective and relatively fast diagnosis of landscape functioning. There is no way how to do it, with the same precision and comparability of information, by field work. Despite the limits, remote sensing data are indispensable tool and method in landscape ecology.

\section{References}

BONAN, G.B. (2008): Forests and Climate Change: Forcings, Feedbacks, and the Climate Benefits of Forests. Science 320, 1444-1449.

CRFEC (2005): Committee on Radiative Forcing Effects on Climate: Radiative Forcing of Climate Change: Expanding the Concept and Addressing Board on Atmospheric Sciences and Climate (BASC). The National Academic Press, NW Washington.

De FRIES, R.S. et al. (2002): Carbon emissions from tropical deforestation and regrowth based on satellite observations for the 1980s and 1990s. PNAS 99 (22), 14256-14261.

FOLEY, J.A. et al. (2003): Green surprise? How terrestrial ecosystems could affect earth's climate. Front Ecol. Environ. 1 (1), 38-44.

FOLEY, J.A. et al. (2005): Global Consequences of Land Use. Science 309, 570-574.

HAIS, M., BROM, J., PROCHÁZKA, J., POKORNÝ, J. (2006): Effect of water drainage on the forest microclimate; case study of two small catchments in the Šumava mountains. Ekológia 25 (3), 18-26.

HAIS, M., JONÁŠOVÁ, M., LANGHAMMER, J., KUČERA, T. (2009). Comparison of two types of forest disturbance using mutitemporal Landsat TM/ETM+ imagery and field vegetation data. Remote sensing of Environment, 113 (4), 835-845.

HESSLEROVÁ, P. (2008): Hodnocení krajinných funkcí pomocí multispektrálních družicových dat Landsat. Ph.D. thesis. Dep. in: Department of Physical Geography and Geoecolgy. Faculty of Science, Charles University in Prague. 
IPCC (2007): International Panel of Climate Change: Contribution of Working Groups I, II and III to the Fourth Assessment Report of the Intergovernmental Panel on Climate Change. Geneva, Switzerland. pp. 104.

JØRGENSEN, S.E., MEJER, H.F. (1979): A holistic approach to ecological modelling. Ecological Modelling 7, 169-189.

KLIMENT, Z., KADLEC, J., LANGHAMMER, J. (2008): Modelling of suspended sediment transport as a result of present land use changes: Case study of Blšanka river catchment area. Catena 73, 286-299.

KUTCH, W.L. et al. (2001): Environmental Indication: A field test of an ecosystem approach to quantify biological self-organization. Ecosystems 4, 49-66.

LEIBOWITZ, S.C. et al. (2000): Modeling Landscape Functions and Effects: A Network Approach. Ecological Modelling 132, 77-94.

LUVALL, J.C., HOLBO, H.R. (1989): Measurements of short term thermal responses of coniferous forest canopies using thermal scanner data. Remote Sensing of Environment 27 (1), 1-10.

MELESSE, A.M. (2004): Spatiotemporal dynamics of land surface parameters in the Red River of the North Basin. Physics and Chemistry of the Earth 29, 795-810.

PATTEN, B.C., HIGASHI, M., BURNS, T.P. (1990): Trophic dynamics in ecosystem networks: Significance of cycles and storages. Ecos Model 51 (1), 1-28.

PECHAROVÁ, E., HAIS, M., SVOBODA, I. (2006): Changes in landscape energy balance as a result of different land use during three time periods. Ekológia 25 (3), 205-214.

POKORNÝ, J. (2001): Dissipation of solar energy in the landscape - controlled by management of water and wegetation. Renewable energy 24, 641-645.

POKORNÝ, J., ŠÍMA, M. (2006): Význam velkoplošných rekultivací pro ochranu klimatu - koloběh vody, energetická bilance krajiny, využití DPZ. - In: Rekultivace a socioekonomické aspekty. Regionální workshop projektu Re-Regions, Most 10.-11. 4. 2006, Krajský úřad, pp. 38-41, Ústí nad Labem.

PROCHÁZKA, J., HAKROVÁ, P., POKORNÝ, J., PECHAROVÁ, E., HEZINA, T., Š́́MA, M., PECHAR, L. (2001): Effect of different management practices on vegetation development, losses of soluble matter and solar energy dissipation in three small sub-mountain catchments. - In: Vymazal, J. (ed.) Transportations of Nutrients in Nature and Constructed Wetlands, Backhuys Publishers, Leiden, pp. 143-175.

RANDERSON, J.T. et al. (2006): The impact of Boreal Forest Fire on Climate Warming. Science 314, $1130-1132$.

RIPL, W. (1995): Management of water cycle and energy flow for ecosystem control: the energy-transportreaction (ETR) model. Ecological Modelling 78, 61-76.

RIPL, W., HILDMANN, CH. (2000): Dissolved load transported by rivers as an indicator of landscape sustainability. Ecological Engineering 14 (4), 373-387.

RIPL, W. (2004): Funktionalle Landschaftsanalyse im Albert Rothschild Wildnisgebiet Rothwald. Study. System Institut Aqua Terra / TU-Berlin, Hellriegelstr. 6, 14195 Berlin.

SAUNDERS, S.C. et al. (1998): Hierarchical relationships between landscape structure and temperature in a managed forest landscape. Landscape Ecology 13, 381-395.

SCHNEIDER, J., KAY, J.J. (1994a): Life is a menifestation of the second law of thermodynamics. Math. Comput. Model 19 (6-8), 25-48.

SCHNEIDER, J., KAY, J.J. (1994b): Complexity and thermodynamics: towards a new ecology. Future 24 (6), 626-647.

SMITH, R.C.G., CHOUDHURY, B.J. (1991): Analysis of Normalized difference and surface temperature observations over southeastern Australia. International Journal of Remote Sensing 12 (10), 2021-2044.

SVIREZHEV, Y.M. (2000): Thermodynamics and ecology. Ecological Modelling 132, 11-22.

ŠíMA, M., POKORNÝ, J. (2006): Detekce a hodnocení vývoje rekultivačního území MUS a.s., pomocí družicových dat Landsat z let 1991-2005. II. Část - rozšíření o období 2000-2005. - Výzkumná zpráva, ENKI, o.p.s., Třeboň.

ULANOWICZ, R.E. (1986): Growth and Development. Ecosystem Phenomenology. New York, Springer. 


\section{Hodnocení funkcí krajiny založené na rozložení radiační teploty}

Článek pojednává o vztahu krajinného pokryvu k radiační teplotě, kterou lze považovat za ukazatel způsobu disipace sluneční energie $\mathrm{v}$ krajině. Pro hodnocení fungování krajiny byla využita multispektrální družicová data Landsat TM, informace o radiační teplotě byly odvozeny z termálního kanálu TM6, a to v relativní škále. Jako modelové území byl zvolen přeshraniční region severních Čech a Saska. Diskutován je vztah disipace sluneční energie k radiační teplotě, její význam pro fungování krajiny. Vlastní interpretace teplotních snímků je založena na teoretickém základu, vycházející z Energy-transport-reaction modelu (Ripl 1995). Podle změn radiační teploty lze hodnotit změny fungování krajiny, a to nejen ve vybraném devítiletém časovém horizontu, ale rovněž v různých fázích vegetačního období.

Informace o krajinném pokryvu byly získány z multispektrálních dat Landsat TM metodami řízené klasifikace (Maximum Likelihood, Fisher Linear Likelihood a ECHO klasifikátor). Byly vymezeny čtyři základní kategorie krajinného pokryvu - vodní plochy, les, nelesní vegetace a holé povrchy. Možnosti rozdělení do dalších subkategorií byly limitovány termínem pořízení snímků - detailnější klasifikační schéma lze většinou extrahovat ze snímků z pozdní fáze vegetačního období. Př́ípadná diferenciace nelesní vegetace na ornou půdu (zemědělské plodiny) a trvalé travní porosty, byla provedena na základě paralelně vizualizované RGB syntézy kanálů TM 4-5-3. Problém představoval především červencový termín 1995. V tomto období je poměrně těžké, díky téměř totožným spektrálním příznakům, odlišit některé druhy nelesní vegetace od listnatých lesních porostů. Mapy relativní radiační teploty zájmového území pro jednotlivé termíny byly vytvořeny z kumulovaného histogramu hodnot termálního kanálu TM6 ekviareální metodou. Bylo vymezeno pět teplotních tříd (každá obsahující cca $20 \%$ pixelů), s označením plochy nejchladnější chladné - středně teplé - teplé - nejteplejší. Přri použití této metody je však nezbytné brát v úvahu, že takto definované a vypočtené tř́ídy relativní teploty, jsou vztažené pouze $\mathrm{k}$ vybranému zájmovému území a budou se tedy lišit podle jednotlivých prípadových studií. Z celkové teplotní mapy byla pod maskou vymezena teplota pro jednotlivé kategorie vegetačního pokryvu - les, nelesní vegetaci a holé povrchy. Mezitermínové hodnocení změn teploty bylo provedeno na základě krosklasifikační maticové analýzy (modul CROSSTAB $\mathrm{v}$ softwaru IDRISI 15.0).

Lesní ekosystémy jsou kategorií krajinného pokryvu, s vysokou disipační schopností. Znamená to, že většina dopadajícího slunečního záření je transformována do latentní složky tepla, které nepřispívá k zvyšování teploty krajiny). Jsou typem porostu, který je schopen vyrovnávat teplotní výkyvy, zadržet vy̌šší obsah vlhkosti a tím zajištovat efektivní disipaci sluneční energie. Pokud nejsou ovlivněny vláhovým stresem, jsou schopny udržovat nízkou teplotu krajiny a vytvářet kondenzační místa. Nelesní vegetaci lze řadit spíše do kategorie s nízkou disipační schopností. Ve většině př́ípadů se jedná o zemědělské, suchomilné plodiny, které trpí silným vláhovým stresem a nejsou schopny efektivní disipace. Intenzita evapotranspirace na těchto plochách je velmi nízká, dominuje vlastní tepelná složka, která přispívá k vysoké teplotě krajiny. Příznivějším chováním se vyznačují některé trvalé travní porosty, zvláště vlhké louky a mokřady. Holé povrchy víceméně přispívají k vysoké teplotě krajiny. Jak však ukazují satelitní data, pozitivní vliv na teplotní obraz může mít i malé množství mrtvé biomasy.

Data DPZ (Landsat - především teplotní kanál TM6) a použité základní metody jejich zpracování prokázaly, že umožňují objektivní, poměrně rychle zjistitelnou diagnózu krajiny, jež nelze se stejnou podrobností, porovnatelností a přesností získat pozemním průzkumem. I přes určité limity, představují data dálkového průzkumu Země nepostradatelný nástroj v krajinné ekologii.

Ačkoli by se mohlo zdát, že řešená problematika je obecně a logicky známá, neexistuje zatím mnoho prací (Foley et al. 2003, 2005; Ripl a Hildmann 2000; Ripl 2004; Pokorný a Šíma 2006; Šíma a Pokorný 2006), které by dokumentovaly význam kategorií krajinného pokryvu a heterogenitu krajinné struktury v návaznosti na teplotu a umožňovaly tak diagnostiku jejího fungování. Data dálkového průzkumu poskytují právě ony často chybějící údaje, podklady a důkazy pro tato tvrzení. To jak je daný problém vzrůstu teploty krajiny závažný, ilustruje obraz intenzivně využívaného regionu Mostecké pánve, Poohří i Polabí.

V dnešní době jsou velmi diskutovaným tématem globální změny klimatu. Ve většině př́ípadů jsou tyto změny dávány zejména do souvislosti se zvyšováním množství skleníkových plynů $\mathrm{v}$ atmosféře, případně albedem povrchu (CRFEC 2005, IPCC 2007, DeFries et al. 2002, Randerson et al. 2006, Bonan 2008). Většina přistupů však zcela opomíjí význam trvalé a funkční vegetace v krajině a procesy evapotranspirace. 
Člověk svou činností ovlivňuje své prostředí. Především intenzifikace zemědělství a urbanizace má značný podíl na narušení energomateriálových toků. Vlivem odvodnění a vysušení krajiny, odstraněním funkční a trvalé vegetace $\mathrm{z}$ krajiny (nejen kácení lesů, ale rovněž úbytek remízků, rozptýlené zeleně a preferencí suchomilných plodin - obilovin), dochází k přehřívání krajiny a její degradaci, způsobenou zrychleným odnosem živin. Př́ikladem nemusí být desertifikované aridní a semiaridní oblasti, ale jak vyplývá z výsledků hodnocení i intenzivně využívaná oblast Polabí a Poohří. Podle prokázaných výsledků, lze navracením trvalé a funkční vegetace do krajiny, a to již na lokální úrovni, příznivě ovlivňovat teplotu a s tím spojený malý oběh vody a následně ovlivnit i klima na úrovni globální. Růst teploty v krajině by mohl být daleko účinněji kontrolován přes vodní cyklus a zapojením funkční vegetace. Vétší teplotní amplitudy mají za následek růst turbulentního proudění, snížení evapotranspirace a poškozování vegetace, zvýšený odnos látek. Obnova základních ekologických funkcí, jakými je právě způsob disipace slunečního záření přes vodní cyklus, je proto možným aktivním obranným krokem proti klimatickým změnám.

Petra Hesslerová

ENKI, o.p.s.

Dukelská 145

37901 Třebon̆

Czech Republic

e-mail:M42barta@seznam.cz phone: +420 384706173

\section{Department of Applied Geoinformatics and Landscape Planning}

Faculty of Environmental Sciences,

Czech University of Life Sciences Prague

Kamýcká 1166

16500 Prague 6

Czech Republic 